\title{
STATISTICAL ANALYSIS OF THE FACTORS OF SUPPLY FORMATION ON THE UKRAINIAN MONEY MARKET
}

\section{СТАТИСТИЧНИЙ АНАЛІЗ ФАКТОРІВ ФОРМУВАННЯ ПРОПОЗИЦІї НА ГРОШОВОМУ РИНКУ УКРАЇНИ}

UDC 311.2:330.1

https://doi.org/10.32843/infrastruct45-41

\section{Pohorielova Tetiana}

Candidate of Economic Sciences, Associate Professor,

Senior Lecturer at the Department of Statistics

Odessa National Economic University Boublik Violeta

Senior Lecturer at the Department of Germanic Languages and Translation Odessa National Polytechnical University

\begin{abstract}
The article contains the results of statistical research of the factors which create supply on the Ukrainian money market. At the stage of a priori analysis the essence of money market from the point of view of supply and demand balance is summarized. Such factors as money basis, money-credit multiplication, inflation level and speed of money circulation, which influence money supply have been found and economically generalized. With the help of correlation-regression analysis, the power of impact of each factor on supply formation on the Ukrainian money market for the period of 20102019 has been assessed. The most impact is done by money basis, speed of money circulation and money multiplication. At the same time, multicollinearity has been found between these factors that helped to exclude some of them from the future analysis. On the basis of statistical data for the period of 2010-2019 the regression model of supply on the money market has been created and analyzed. It helped to focus attention on the fact that supply on the Ukrainian money market mostly depends on money basis. The results of the research can be used in the development and implementation of monetary policy of the state. Key words: money market, supply factors, correlation and regression analysis, money supply, money basis, speed of money turnover, correlation factors, regression model.
\end{abstract}

Статья содержит результаты статистического исследования фракторов, которые фрормируют предложение на денежном рынке Украины. На стадии априорного анализа обобщена сущность денежного рынка с позиции уравновешивания спроса и предложения. Выявлены и экономически обоснованы фракторы, влияющие на предложение денее: денежная база, денежно-кредитный мультипликатор, уровень инсрляции и скорость обращения массы. С помощью корреляционно-регрессионного анализа оценена сила влияния каждого из факторов на формирование предложения на денежном рынке Украины за период 2010-2019 г2. Наиболее существенно влияют денежная база, скорость обращения денег и денежный мультипликатор. В то же время между фракторами выявлена мультиколлинеарность, что позволило исключить некоторые из них из дальнейшего анализа. На основе статистических данных за период 2010-2019 г2. построена и проанализирована регрессионная модель предложения на денежном рынке. Это позволило акцентировать внимание на том, что предложение на денежном рынке Украины зависит прежде всего от денежной базы. Полученные результаты исследования могут быть использованы при разработке и проведении монетарной политики государства.

Ключевые слова: денежный рынок, факторы предложения, корреляционно-регрессионный анализ, денежная масса, денежная база, скорость обращения денег, коэфрфициенты корреляции, регрессионная модель.

Сучасний розвиток України орієнтований на впровадження ринкових механізмів в національну економіку. Провідна роль у цьому процесі відводиться організації та адаптації грошового ринку до світових стандартів, визначенню фракторів, які фрормують попит та пропозицію, що неможливо без надійної та своєчасної статистичної оцінки. У статті представлені результати статистичного дослідження фракторів, які формують пропозицію на грошовому ринку України. Узагальнено теоретичні підходи до визначення грошового ринку з позиції урівноваження попиту та пропозииії. Виявлено та економічно обгрунтовано фрактори, які формують грошовий попит: грошова база, грошово-кредитний мультиплікатор, рівень інфрляції та швидкість обертання грошової маси. Проаналізовано інтенсивність їхнього розвитку за період 2011-2019 роки. Кількісним виразом грошової пропозиції пропонується вважати обсяг національної грошової маси. За допомогою кореляційного аналізу оцінено силу впливу кожного запропонованого фрактору на пропозицію, що склалася на грошовому ринку Украӥни за період 2010-2019 рр. Найбільш вагомо впливають три фрактори: грошова база, швидкість обертання грошей та грошово-кредитний мультиплікатор. Одночасно між грошовою базою та швидкістю обертання грошової маси виявлено мультиколинеарність. Відповідно статистичним критеріям та постулатам економічної теорії у подальшому дослідженні перевагу надано грошовій базі як фрактору, який більш тісно пов'язано з пропозицією грошей. За статистичними даними 2010-2019 рр. побудовано та проаналізовано регресійну модель пропозиції на грошовому ринку. Це дозволило акцентувати увагу на те, що пропозиція на грошовому ринку України залежить насамперед від грошової бази. За допомогою розрахунку коефіцієнта еластичності оцінено відносний вплив грошової бази на пропозицію на грошовому ринку України. Отримані результати не суперечать висновкам класичної теорії грошового ринку, що зростання грошової пропозиції неможливе без адекватного емісійного потенціалу. Результати дослідження можуть бути використанні під час розробки та проведення монетарної політики держави.

Ключові слова: грошовий ринок, фрактори пропозиції, кореляційно-регресійний аналіз, грошова маса, грошова база, швидкість обігу грошей, коеріцієнти кореляції, регресійна модель.

Problem formulation. The basis of economic growth is the transformation of monetary relations in accordance with international standards, which is based on a sound reform of the monetary system and monetary policy of the state. An important role in this process is played by the statistical analysis of the money market, in order to identify the factors that balance money supply and demand.

Analysis of recent studies and publications. The analysis of the money market was done in the works of many international and home scientists, particularly John. M. Keynes, John. Hicks, N. Friedman, I. Fischer, 
V. Mishchenko, V. Stelmakh, V. Salina, N. Davidenko, $\mathrm{N}$. Saluka and others. Without diminishing the scientific importance of leading experts, it is worth saying that the statistical study of the relationship between supply factors on the money market of Ukraine, first of all, the use of multifactor correlation and regression analysis has not been fully disclosed yet.

Task formulation. The aim of the study is to identify the factors that create supply on the monetary market of Ukraine, statistical estimation of their impact with the help of correlation and regression analysis.

Presentation of the research. Modern economic concept is not quite certain about the interpretation of the monetary market. There are two aspects of this problem. Mostly the money market is identified with the financial market or is considered to be an integral segment. This opinion is shared by a number of economists, for example, V. Vartsaba., V. Ohorodnyk [1], D. Dema [2, pp. 111-126], N. Davydenko [3], Y. Litvinenko [4]. According to their studies, not only money but also short-term securities are circulated on the money market, that is what creates supply and demand.

Representatives of different scientific trends, for example A. Halchinskiy [5], N. Savluk [6, pp. 72-91], consider money market as an independent mechanism for regulation of money supply and demand.

In the framework of statistical monitoring of the factors that determine the supply on the money market, the latter should be viewed as a component of the financial market, where supply and demand are formed, but not only where money is sold and bought.

The economic reality of Ukraine must pay attention to peculiarities of formation and interaction of factors influencing the money market, as the classical display of money supply in a transition economy can be deformed and objectives of the statistics are to research them in time.

The main component of the market mechanism is money supply that is the aggregate of purchasing, payment and accumulation funds, which service the economic relations and belong to individuals and legal entities and the state. It is the amount of money overall, that can be regarded as cash supply or demand, which is formed on the monetary market of Ukraine. The estimation of money supply is presented in the static survey of the NBU in the form of monetary aggregates. The analytical value of research, in our opinion, is presented by the MO (cash) and M3 (money supply). For the period of 2011-2019, cash in Ukraine has been increasing by $8.6 \%$ on average annually while the total money supply has been increasing by $10.2 \%$ (calculated according to [7]). Since the calculation of $M 3$ is based on volumes of cash (M0), the attention in our further research will be paid to M3.

Key indicators of the supply on the monetary market are generally considered the monetary basis and the monetary multiplier [8; 9]. This dependence can be expressed statistically as follows:

$$
M S=f(m, M B)
$$

where $M_{S}$ - the money supply; $m$ - the money multiplier, $M_{B}$ - the monetary basis.

Thus, the change in the money supply on the market is caused by the dynamics of factors affecting the monetary basis and the money multiplier.

Usually, the monetary basis is regarded as an independent component of the money supply, which characterizes the amount of funds received by commercial banks of the country and controlled by the NBU. Therefore, the amount of the monetary basis depends on banking operations (credit, currency, etc.). In its turn, the money multiplier measures the increase in the money supply as a result of non-cash issue and depends on the banking sector and economic factors that impact this sector (national wellbeing, the shadow economy, the level of trust in the banking system, etc.). So, for the period of 2011-2019 in Ukraine, the monetary basis has increased annually by $8.7 \%$ and cash multiplier by $1.6 \%$. That is, the average relative growth rate of the monetary basis exceeded the average relative growth rate of the money multiplier 5.4 times (calculated according to [7]). As you can see, the impact of these banking indicators has been controversial: the supply on the monetary market of Ukraine has been formed primarily as a result of changes of the monetary basis and issuing potential but economic factors (the market conditions of commercial banks, their ability to create reserves) had almost no influence on it.

Based on modern theory of money, in addition to two factors - the volume of monetary basis and the money multiplier, which became traditional, it is possible to extend the list of factors that determine the supply on the money market. They include, in particular, the velocity of money, the inflation rate of the economy. Thus we will consider their economic essence and the degree of influence on the money supply.

Classical monetary approach assumes that money circulation depends on the velocity of money circulation. The higher it is, the smaller amount of money is required on the market, the lower is the demand and vice versa. The velocity of money depends on many economic and even political factors, therefore, anyway they affect the money supply. In 2011-2019 the velocity of circulation of money supply on average annually increased by $4.8 \%$. The average annual growth rate of the money supply outpaced the growth rate of money almost 2 times (calculated according to [7]). Therefore, there was some disparity between supply and demand.

Such factor as inflation influences money supply in several ways. In terms of inflationary rise in prices, money supply that subjects of the economy have inevitably depreciates and they will suffer losses, 
and it results in the decrease of money demand and growth of its supply. In addition, inflationary rise in prices is pushing up the interest rate and all other anticipated income from assets which are alternatives to money. As a result of this process, there is a rise in the value of cash reserves and money supply increases. However, you need to take into consideration the fact that the price increase has a positive impact on the supply if it is not significant and does not provoke inflationary expectations.

Expectations of a downturn on the markets are closely connected with the inflation in particular the reduction of goods, trade deficit increase, rise in unemployment, and decline in product quality. In such conditions, economic entities strive to accumulate commodity wealth, but not cash, and the demand for money is reduced.

Theoretical a priori analysis and availability of statistical data proved that the main factors that influence the formation of supply on today's monetary market are velocity of money circulation and inflation.

Based on the above mentioned facts, the model of supply on the money market (1) can be transformed as follows:

$$
M S=f\left(m, M_{B}, l, V\right),
$$

where $m$ - the money multiplier, $M_{B}$ - the monetary basis; $I-$ the rate of inflation; $V$ - velocity of money circulation.

According to its economic nature, the model of money supply (2) is stochastic, as in reality supply on modern money market is influenced by a whole range of factors considered, which are closely intertwined and interact. Thus, we will combine the qualitative analysis and the analysis of pair coefficients and indices of correlation and their significance. To solve this problem we compose a matrix of pair correlations, which measure the density of the linear relationship of each factor and the effective index (supply) and all other factors (Table 1). All the necessary calculations of correlation and regression were done with the help of Microsoft Excel program.

The relationship between money supply and the factors affecting it is considered to be close under the conditions $0.7<\left|r_{Y X}\right|<1.0$ [12]. A close direct relationship was observed between the volume of money supply and monetary basis $\left(r_{Y X 1}=0.995\right)$, money supply and the speed of its circulation $\left(r_{Y x 4}=0.825\right)$. The average level of connection is observed between the volume of money supply and the money multiplier $\left(r_{Y X 2}=0.552\right)$. The connection between the volume of money supply and inflation rate is weak $\left(r_{Y \times 3}=0.091\right)$, so inflation does not significantly affect the formation of supply on the monetary market of Ukraine.

At the same time, this correlation matrix allows to identify the factors that are all together in close correlating linear relationship very close to functional. As you can see from Table 1, there is multicollinearity between the factors that influence demand on the money market, the monetary basis and the rate of turnover of the money supply $\left(r_{14}=0.827\right)$. One of them should be excluded from further analysis. Preference is given to the monetary basis, which is more closely associated with the money supply, and the trend of its dependence fully corresponds to the economic views.

So, the correlation analysis proved that during 2010-2019, the supply on the monetary market of Ukraine was formed primarily under the influence of the monetary basis and coincided with the calculations of the coefficients which had been done before.

The purpose of the final choice of factors that form supply on modern money market is done to estimate a multiple regression equation. Implementation of the statistical machine KRA allowed us to obtain the following regression model:

$$
\hat{Y}=-71,7+3,1 X_{1}
$$

The index of the regression coefficient $a_{1}$ corresponds the economic ideas of the influence of monetary basis on supply, which prevails on the monetary market of Ukraine. For the period of 2010-2019 with the growth of the monetary basis by $1 \mathrm{bln}$. money supply increased on average by 3.1 billion UAH.

According to all statistical parameters (Table 2), the obtained regression model of the money supply (3) is statistically significant, reliable and adequate.

Data analysis in Table 2 shows a close correlation between supply on the monetary market of Ukraine and the monetary basis in 2010-2019 that characterizes the dependence of the variables in the regression model (3). As we have analyzed a few samples $(\mathrm{N}<20)$, it is advisable to take into account the normalized

Matrix of paired linear coefficients of correlation between the factors of supply formation on the monetary market of Ukraine for the period of 2010-2019

\begin{tabular}{|l|c|c|c|c|c|}
\hline \multicolumn{1}{|c|}{ Index } & $\mathbf{Y}$ & $\mathbf{X 1}$ & $\mathbf{X 2}$ & $\mathbf{X 3}$ & $\mathbf{X 4}$ \\
\hline Money supply $-\mathbf{Y}$ & 1.000 & & & & \\
\hline Monetary basis $-\mathbf{X 1}$ & 0.995 & 1.000 & & & \\
\hline Money multiplier - X2 & 0.552 & 0.480 & 1.000 & & \\
\hline Inflation rate $-\mathbf{X 3}$ & 0.091 & 0.109 & -0.173 & 1.000 & \\
\hline $\begin{array}{l}\text { The velocity rate of money supply } \\
\text { circulation - X4 }\end{array}$ & 0.825 & 0.827 & 0.462 & -0.072 & 1.000 \\
\hline
\end{tabular}

Source: developed by authors according to [7; 10; 11] 
Results of building and analyzing the regression supply model

on the monetary market of Ukraine for the period of 2010-2019

\begin{tabular}{|l|c|}
\hline \multicolumn{1}{|c|}{ Index 1. The accuracy of correlation } \\
\hline \multicolumn{1}{|c|}{ The value of the index } \\
\hline 1.1. The coefficient of multiple correlation is $\mathrm{R}$ & 0.995 \\
\hline 1.2. The coefficient of determination R-squared & 0.991 \\
\hline 1.3. The normalized R - square & 0.989 \\
\hline \multicolumn{2}{|c|}{ 2. Reliability } \\
\hline 2.1 F- criterion & 867.053 \\
\hline 2.2. $\mathrm{p}$ - significance & $1.917 \cdot \mathrm{E}-9$ \\
\hline \multicolumn{2}{|c|}{0.285} \\
\hline 3.1. The coefficient of autocorrelation of leftovers & $0 ., 457$ \\
\hline 3.2. $\mathrm{R}$ - significance & \\
\hline
\end{tabular}

Source: developed by authors according to [7; 10; 11]

coefficient of determination ( $R$ - square). So, despite few samples of the original data, the regression model of demand (3) is very accurate, that is, $98.9 \%$ of the supply variations (the volume of money supply) take place due to changes in the monetary basis.

To analyze the reliability and adequacy of the regression model, it is advisable to use modern approach. Taking into account the fact that the level of calculated significance of F-test lower than accepted $(1.917 \mathrm{E}-9<0.05)$, it can be proved that the supply model (3) as a whole is statistically significant and reliable [12]. This conclusion is confirmed by the autocorrelation coefficient of the first order, the value of which is positive and small. So, we come to the conclusion that the regression model of supply on modern money market adequately describes the dependence of the proposed money supply on the monetary basis of the country in the period of 2010-2019.

The coefficient of elasticity analyzes the relative impact of monetary basis on money supply on the market of Ukraine:

$$
E=a_{1} \frac{\bar{X}}{\bar{Y}}=3,1 \frac{339,1}{987,6}=1,1(\%),
$$

where $a_{1}-$ is the regression coefficient; $\bar{X}-$ the average factor (the monetary basis); $\bar{Y}$ - average effective attribute (the money supply).

The received coefficient of elasticity shows that for the period of 2010-2019 together with the growth of the monetary basis by $1 \%$, money supply increased by $1,1 \%$ on average.

Conclusions of the research. Thus, with the help of correlation and regression analysis, we have revealed the factors affecting supply on the money market of Ukraine: monetary basis, money multiplier, inflation and velocity of money circulation, and estimated their impact. The creation and analysis of regression model of money supply for the period of 2010-2019 helped us to come to conclusion that the main factor of supply formation on the monetary market of Ukraine is the monetary basis above all. However, the growth of the monetary basis must be supported by the growth in the real sector of the national economy. Therefore, among other factors that influence supply, it is advisable to pay special attention to the index the GDP deflator, exchange rates, monetization of GDP and their dynamics.

Applied statistical approach can be used to identify factors that impact conditions and development of the money market, to confirm the main postulates of economic development and monetary policy, which should be directed to ensure stability and sustainability of the national economy.

\section{REFERENCES:}

1. Vartsaba V. I., Ohorodnyk V. O. (2017) Hroshovyi rynok Ukrainy $v$ konteksti transformatsiinykh protsesiv [The money market of Ukraine in the context of transformation processes]. Ekonomika ta derzhava, no. 10, pp. 9-12. Available at: http://www.economy.in.ual pdf/10_2017/4.pdf (accessed 4 June 2020).

2. Dema D. I., Abramova I. V., Nedilska L. V. (2017) Finansovyi rynok: navch. posib. [Financial market : textbook]. Zhytomyr : DNAEU(in Ukrainian).

3. Davydenko N. M. (2017) Suchasnyi stan hroshovoho rynku ta osoblyvosti emisii hroshei v Ukraini [The current state of the money market and features of money issuance in Ukraine]. Scientific Bulletin of Kherson State University, no 27 (part 3), pp. 20-24. Available at: http://www.ej.kherson.ua/journal/economic_27/3/6.pdf (accessed 4 June 2020).

4. Lytvynenko Ya. V. (2009) Hroshovyi rynok: yoho sutnist ta osoblyvosti rozvytku $v$ Ukraini [Money market: its essence and features of development in Ukraine]. Collection of scientific works "Theoretical and practical aspects of economics and intellectual property". Available at: http://eir.pstu.edu/bitstream/ handle/123456789/17272/62.pdf?sequence=1 (accessed 25 May 2020).

5. Halchynskyi A. S. (2001) Teoriia hroshei : navch. Posib. [Theory of money: a textbook]. Kyiv: Osnovy. (in Ukrainian). 
6. Savluk M. I., Moroz A. M., Lazepko I. M. (2011) Hroshi ta kredyt : pidruchnyk [Money and credit: a textbook]. Kyiv: KNEU. (in Ukrainian).

7. Website of the National Bank of Ukraine. Sait Natsionalnoho Banku Ukrainy. Available at: https://bank.gov.ua/ua/statistic (accessed 5June 2020).

8. Barida N. P. (2013) Groshova propoziciya ta iii vpliv na social'no-ekonomichnij rozvitok [Money suggestion and his influence are on socio-economic development.]. Efektivna ekonomika, no 5. Available at: http://www.economy.nayka.com.ua/?op=1\&z=2062 (accessed 27 June 2020).

9. Poplyujko Ya. V. (2015) Kompleksnij ekonomikostatistichnij analiz propoziciï groshej $v$ Ukraïni [Comprehensive economic and statistical analysis of the money supply in Ukraine]. Efektivna ekonomika, no. 10. Available at: http://www.economy.nayka.com.ua/ pdf/10_2015/42.pdf (accessed 25 June 2020).

10. Website of the State Statistics Service of Ukraine. Available at: http//www.ukrstat.gov.ua (accessed 5 June 2020).

11. Website of the Ministry of Finance of Ukraine. Available at: https://index.minfin.com.ua/ua/economy/ gdp/2019/ (accessed 5June 2020).

12. Yankovoj O.G. (2001) Modelyuvannya parnix zvyazkiv $\vee$ ekonomici : navch. posibnik [Modeling of paired relationships in economics: a textbook]. Odesa Odesa: Optimum (in Ukrainian).

\section{БІБЛІОГРАФІЧНИЙ СПИСОК:}

1. Варцаба В. І., Огородник В. О. Грошовий ринок України в контексті трансформаційних процесів. Економіка та держава. 2017. № 10. C. 9-12. URL: http://www.economy.in.ua/pdf/10_2017/4.pdf (дата звернення: 4.06.2020).

2. Дема Д. І., Абрамова І. В., Недільська Л. В. Фінансовий ринок : навч. посіб. / за заг. ред. Д. І. Деми. Житомир : ДНАЕУ, 2017. 448 с.
3. Давиденко Н. М. Сучасний стан грошового ринку та особливості емісії грошей в Україні. Науковий вісник Херсонського державного університету. 2017. № 27 (Ч.3). С. 20-24. URL: http://www.ej.kherson.ua/journal/economic_27/3/6.pdf (дата звернення: 4.06.2020).

4. Литвиненко Я. В. Грошовий ринок: його сутність та особливості розвитку в Україні. Збірник наукових праць «Теоретичні та практичні аспекти економіки та інтелектуальної власності». Маріуполь: ПДТУ, 2009.URL: http://eir.pstu.edu/bitstream/handle/123456789/17272/62. pdf?sequence $=1$ (дата звернення: 25.05.2020).

5. Гальчинський А. С. Теорія грошей : навч. посіб. Київ : Основи, 2001. 413 с.

6. Савлук М. І., Мороз А. М., Лазепко І. М. Гроші та кредит : підручник / за заг. ред. М. І. Савлука. Київ : KHEУ, 2011.589 c.

7. Сайт Національного Банку України. URL: https:// bank.gov.ua/ua/statistic (дата звернення: 5.06.2020).

8. Баріда Н. П. Грошова пропозиція та її вплив на соціально-економічний розвиток. Ефрективна економіка. 2013. № 5. URL: http://www.economy.nayka.com.ua/ ?op=1\&z=2062 (дата звернення 27.06.2020).

9. Поплюйко Я. В. Комплексний економікостатистичний аналіз пропозиції грошей в Україні. Ефективна економіка. 2015. № 10. URL: http:// www.economy.nayka.com.ua/pdf/10_2015/42.pdf (дата звернення 25.06.2020).

10. Сайт Державної служби статистики України. URL: http://www.ukrstat.gov.ua (дата звернення: 5.06.2020).

11. Сайт Міністерства фрінансів України. URL: https://index.minfin.com.ua/ua/economy/gdp/2019/ (дата звернення: 5.06.2020).

12. Янковой О. Г. Моделювання парних зв'язків в економіці : навч. посібник. Одеса: Оптимум, 2001. $198 \mathrm{c}$. 